\title{
Microalgae: An emerging source of energy based bio-products and a solution for environmental issues
}

\author{
Richa Katiyar ${ }^{1 *}$, B. R. Gurjar ${ }^{2}$, Shalini Biswas ${ }^{1}$, Vikas Pruthi ${ }^{3}$, Nalin Kumar ${ }^{4}$ and \\ Prashant Kumar, 6
}

${ }^{1}$ Centre for Transportation Systems, Indian Institute of Technology Roorkee - 247667, Uttarakhand, India

${ }^{2}$ Department of Civil Engineering and Centre for Transportation Systems, Indian Institute of Technology Roorkee - 247667, Uttarakhand, India

${ }^{3}$ Department of Biotechnology and Centre for Transportation Systems, Indian Institute of Technology Roorkee - 247 667, Uttarakhand, India

${ }^{4}$ Department of Biochemical Engineering and Biotechnology, Indian Institute of Technology Delhi, New Delhi - 110016, India

${ }^{5}$ Department of Civil and Environmental Engineering, Faculty of Engineering and Physical Sciences (FEPS), University of Surrey, Guildford GU2 7XH, United Kingdom

${ }^{6}$ Environmental Flow (EnFlo) Research Centre, FEPS, University of Surrey, Guildford GU2 7XH, United Kingdom

*Corresponding author. Email: katiyar.richa10@ gmail.com; Phone: +91-8445414105

\begin{abstract}
The microalgae biomass is emerging as a potential source of energy and bioproducts with several advantages over conventional crops in terms of its ability to produce $\sim 300$-times more renewable oil. Microalgae also have a high photosynthetic response, product accumulation rate and biomass production rate compared with other energy crops. Microalgae have the ability to grow on nonagricultural soil using wastewater instead of drinking water. Furthermore, microalgae have high capability to fix carbon dioxide from the environment. Microalgae-based bioproducts have different applications in pharmaceuticals, food and feed industries, and agricultural and transportation sectors. The key objectives covered in this review pertain to the role of microalgae to (i) maintain food chain, (ii) conservation of land and water resources in the environment with sequestration of $\mathrm{CO}_{2}$, (iii) production of energy in the form of biodiesel with zero waste, and (iv) simultaneous release of higher oxygen to the environment compared with other energy crops.
\end{abstract}

Keywords: Bioenergy; Biofuel; Biorefinery products; Biomass; Photosynthetic response 


\section{Introduction}

The Earth's atmosphere during the Cambrian period about 500 million years ago was anaerobic and had plenty of $\mathrm{CO}_{2}$ of the level of 7,000 parts per million compared with 400 parts per million currently in the natural environment. The existence of life on earth was started by cynobacteria and microalgae via performing photosynthesis with the release of oxygen [1]. These small organisms utilize solar energy to produce their biomass.

The idea of using microalgae as a source of energy came forward around 50 years ago, but real progress started in the $20^{\text {th }}$ century [2]. In contrast of other energy crops, microalgae have a number of valuable properties such as high photosynthetic efficiency, high product accumulation rate [3], biomass production rate, cellular carbon to nitrogen $(\mathrm{C}: \mathrm{N})$ and carbon to phosphorous $(\mathrm{C}: \mathrm{P})$ ratios $[4,5]$. Harvesting period of microalgae is very less in few days compared with terrestrial plants such as jatropha takes 2-3 years. Some species of microalgae can yield up to $70 \%$ of lipid as a total weight for the production of oil with simultaneous production of biorefinery products include glycerin and fertilizers, which possess industrial applications. In addition, microalgae have the capability to produce other valuable products such as PUFAs, carotenoids, terpenes and lectins which are presumed as future of a number of industries, including pharmaceutical, biotechnology, nanotechnology, feed industry and energy industries [6].

The production of bioenergy in order to meet environment sustainability is one of the most important factors associated with the economic development of the country. Already existing reviews [7] of first and second generation biofuels (i.e. those produced from food and nonfood crops, respectively) have shown a number of unsolved problems such as food versus fuel, land effect and biodiversity loss debates. In order to overcome those existing problems the energy extraction has shifted towards other alternative resources such as waste materials includes, waste oils, greases and microorganisms such as bacteria. However, these alternative resources are questionable in terms of fulfilling demand for petroleum-based fuels. To overcome these challenges microalgae is considered as more satisfactory resources in fulfilling demand for petroleum-based fuels and that microalgae are also involved in the maintenance of food web, water balance and stop deforestation. Microalgae also help in resolving food versus fuel debate associated with food crops, land effect and carbon sequestration processes. Furthermore, microalgae have the ability to consume wastewater with high nutrients and can be grown on wasteland for their growth in contrast of other 
energy crops such as jatropha [8]. Thus, negative repercussions associated with other energy feedstocks can be resolved with the usage of microalgae as an energy feedstock for production of value edit products.

The aim of this review article is to focus on lipid accumulation and production of algal biomass which is a target element for biodiesel production with zero waste outcomes. Thus, each unit of energy can be used and recycled for increasing the cost effectiveness of energy extraction process. This review also addresses the essential products, benefits of using microalgae with providing the related abetment of environment and waste water with the possible maintenance of food chain.

\section{Microalgae}

Microalgae are unicellular and microscopic plants, customarily found in natural and marine water. About 0.2 to 0.8 million of microalgae breathe; out of which about 35,000 species are elucidated [9]. These are considered as primary producers and are able to fix nearly $50 \%$ of the global carbon $(77 \%)$ with the production of oxygen, $\mathrm{O}_{2}[10]$.

Microalgae have many advantages over energy crops and therefore are an attractive alternative for energy production. Microalgae are tolerant to environmental stresses such as temperature and $\mathrm{pH}$ which allow them to reserve more food component (lipids) in the form of energy (oil) [11]. One of the most valuable food components of microalga is lipid bodies, which turn into oil production that has main application in the transport sector. Many countries including Germany, India, USA, China and Japan are using blending of biodiesel with conventional fuel in transportation sector [12]. Volkswagen Group has operated vehicles with biofuels (B20: 20\% biodiesel and 80\% conventional diesel) and British Royal run train successfully using B100 (100\% biodiesel) in 2007 while Eastern Washington ran using B25 in 2008 (Berkeley biodiesel). In India, many busses in Gandhinagar and some national trains such as Jan Shatabdi have run using B5 and B20 in 2004 [13].

However, the scarcity of existing fuels due to limited reserves is a heightened problem these days. Many energy resources such as food and non-food crops as well as waste materials and microorganisms have been studied and implemented practically with a number of success and failures. Every resource has its own benefits and obstacles at practical and industrial scale. But among all currently available energy resources microalgae seem as a fantastic alternative in every respect due to its high product yield rate in the form of biofuels than other energy 
crops and microorganisms [14]. Moreover, microalgae do not compete with the demand for food, water and land for their cultivation. Additionally, microalgae are also involved in the carbon neutral process of biofuel production and emission which maintains carbon cycle in the environment. Thus, switching toward microalgae than other energy crops and microorganism can fulfil today's fossil fuel demand with providing a solution of existing problems. In spite of this, the added advantages may also include the regional and rural development of nation with the cultivation of microalgae on waste land with the use of waste water which would not affect natural resources. Consequently, the complete output of using microalgae may come in the form of energy supply and socioeconomic welfare of developing a country.

\subsection{Diversity in cellular composition of microalgae}

Compositions of microalgae alter over a wide range of modification during its cultivation and species used. Microalgae mainly have an unusual proportion of carbon, hydrogen, nitrogen and phosphorous etc. Mostly algae contain the following composition: $\mathrm{CO} 0.48 \mathrm{H} 1.83 \mathrm{~N} 0.11 \mathrm{P} 0.01$ [15] and have various constituents primarily, including protein (30$40 \%)$, lipid (10-20\%) and carbohydrate (5-15\%) during early stationary phase with high nutritional index in contrast to other energy resources, for example, Chlorella has high protein content $(58 \mathrm{gm} / 100 \mathrm{gm})$ compared with wheat $(13 \mathrm{gm} / 100 \mathrm{gm})$, chicken $(24 \mathrm{gm} / 100 \mathrm{gm})$ and fish (18-24gm/100gm). Each group of microalgae yields a different proportion of hydrocarbon, lipids, and proteins, as listed in Table 1. The high degree of agglomeration of the specified products in microalgae can be achieved by changing the chemical composition of cultivation medium and environmental factors such as temperature, illumination, $\mathrm{pH}, \mathrm{CO}_{2}$ supply, salt and nutrients for high lipid (targeted element for biodiesel production) yield for biodiesel production. Thus, the demand of microalgae is continuously increasing due to its high nutritional value like the use of microalgae as food supplements for fishes in aquacultures and for swine and chickens in poultry. Currently, many producer companies

such as Blue Biotech (Germany), Soliance (France) and BioReal (Sweden) are supplying microalgae products in the form dietary substitute (Chlorella, Spirulina and Astaxanthin), cosmetic products, anti-inflammatory products and slimming products in the market. Thus, the continuous bloom of microalgae in future may fulfil the demand of essential components of food, feed, energy, pharmaceuticals and cosmetics.

\subsection{Lipid content of microalgae}


The lipid is the main component of algal biomass for production of oil/biodiesel [19]. High lipid content reflects high biodiesel production from microalgae cell. Different species of microalgae have different amounts of lipid in contrast with other plants, as given in Figure 1. Certain microalgae usually achieve high lipid content under stress conditions such as limit of nitrogen [20], phosphorous [21], iron [22], salinity [23], silicon [19], effect of light [24], and effect of temperature [25]. Under these stress conditions, they can store up to $72 \%$ of their weight as lipids that transesterified to produce biodiesel, which can be sold for use in automobiles [26]. For instance, Scenedesmus species (sp.) of microalgae show $43 \%$ of dry weight ( $\mathrm{dw}$ ) and $>30 \%$ of dw lipids in a deficiency of nitrogen deficiency and phosphorous, respectively [27]. Chlorella vulgaris showed $40 \%$ and $56.6 \%$ dry cell weight (dcw) lipid contents when cultivated in medium with low nitrogen and iron supplement, respectively [22]. The increase in temperature can also increase lipid content in microalgae for example in N. oculata, shows $7.90-14.92 \%$ increase in lipid content during high-temperature condition during its cultivation. The cultivation temperature of algae can also change the fatty acid profile, for example, a temperature below $20^{\circ} \mathrm{C}$ increases eicosapentaenoic acid (EPA) rather than to increase free fatty acid [28]. Thus, 20-30\% of lipid content can be easily induced in different species of microalgae under different stress conditions [11].

Nitrogen is considered as crucial material for protein synthesis, but its starvation during the cultivation condition is accompanied by the curtailment in the structure of a small subunit of RuBisCO enzyme which is required for protein synthesis [29]. Thus, alteration in RuBisCO due to nitrogen limitation causes inhibition of protein, which allows main carbon resource flow to synthesize more lipids via accretion of enzyme acetyl-CoA carboxylase involved in the first footstep of lipid biosynthesis [30]. However, some species of microalgae such as Nitzschia closterium and $f$. minutissima accumulate lipid under nitrogen limited stress, via a decrease in soluble protein instead of increasing ACCase enzyme activity [31].

Algae can be grown in a combination of altered conditions to increase in lipid yield [32] such as Haematococcus pluvialis yields, $34.85 \%$ (dw) total lipid, when grown under continuous elevated light intensity with altered nitrogen conditions [33].

Lipid accumulation in microalgae also depends on upon its growth phase. For instance, lipid content during limit of nitrogen in $N$. oculata during diverse growth phases such as exponential, near the beginning of stationary and end of stationary phases were accounted for $30.80 \%, 39.70 \%$ and $50.40 \%$, respectively [33]. During the end of the stationary phase, the 
highest yield of lipid is recorded due to the production of non-growth associated product formation. Non-growth associated product formation related to maximum rate of metabolism with zero growth rates due to lack of at least one necessary substrate in medium, which causes the highest accretion of the product rather than increase in growth of cells during the late stationary phase.

Besides the factors noted above, the type of cultures (autotrophic and heterotrophic) may also affect the lipid production in microalgae [34] such as heterotrophic cultures are more consistent than autotrophic cultures because they give high cell density and yield due to its independence on the light. Chlorella sp. produces high cell density $(51.2 \mathrm{~g} / \mathrm{l})$ in heterotrophic culture condition which is ten times higher than autotrophic culture cell density [18], While heterotrophic Chlorella protothecoide yield 55.20\% dw lipid, which is about 3-4 times higher than autotrophic Chlorella protothecoide (14.57\% dw lipid).

All the above-discussed conditions allow microalgae to accumulate a notable amount of lipid to contribute to relatively higher biodiesel production. Microalgae come across as a better option for biodiesel production in contrast of other crops such as jatropha. Its ability to grow and yield sufficient lipid in under of natural, artificial as well as in stress environmental condition, make them an incredible choice, In contrast, other energy crops need controlled conditions to give output. Additionally, the lipid content of microalgae has significant characteristics include saturated and polyunsaturated fatty acids (PUFAs) both which can be used in a different application in the feed as well as in energy generation etc. Many species of microalgae have the capability to produce long chain PUFAs in contrast of higher plants, this increases its demand in food and feed industry. Hence, high lipid content is associated with the various aspects such as biodiesel production and other applications include food and feed additives.

\subsection{Lipid synthesis in microalgae}

Microalgae are a photosynthetic microorganism, possessing the capability to convert $\mathrm{CO}_{2}$ into sugars, which use to produce acetyl-CoA (coenzyme A) by following more than one pathway. Acetyl-CoA behaves as the originator in the fatty acid synthetic pathway which takes place in chloroplast. Fatty acids are basic units of many cellular lipids including triacylglycerols (TAGs) commonly known as oil bodies. In fatty acid synthetic pathway, a multifunctional enzyme complex, i.e. acetyl-CoA carboxylase (ACCase) plays an important role by producing malonyl-CoA from acetyl-CoA and bicarbonate. Finally, these fatty acid 
moieties enter into the endoplasmic reticulum (ER) for glycerolipid synthesis. TAGs synthesis in microalgae varies due to alteration in enzymes activity (ACCase) involved in TAGs synthesis pathway [35]. In further steps, TAGs are formed by the sequential acylation of glycerol-3-phosphate (G3P) backbone with three acyl-Co-A, in ER. The TAGs accumulated in a specific domain of ER, which buds out from the ER forming distinct cellular organelles.

Depending upon the species of microalgae the TAGs content yield may vary. Microalgae may yield high TAGs amount due to its high surface area to volume ratio in contrast to other energy crops. This ratio leads to more nutrients uptake rate and enhances acquisition of desired product such as lipid/TAGs for biodiesel production. Additionally, this ratio also provides microalgae to tolerate the environmental stresses, which make them an attractive alternative for energy extraction than other terrestrial plants.

\subsection{Production of biofuel/oil from microalgae}

Microalgae are popular for their biofuel/oil producing efficiency in contrast to other plants, as seen from the yield data presented in Table 2. On account of this positive aspect, they have emerged as a viable alternative to produce diesel/petroleum fuels. The purpose of this review is to provide the idea of microalgae energy content in the form of oil/biodiesel and other valuable product with the solution of existing problems related to other energy resources. The oil content of microalgae is directly proportional to the amount of lipid content, which can be enhanced by many ways as discussed earlier. Different species of microalgae can increase oil yield up to $90 \%$ under stress condition. It is being expected that by 2030 , oil consumption will be increased to 106 million bbl/day [36]. None of the existing resources except microalgae are capable of fulfilling this growing demand. It is being expected that algal biofuels have the potential to replace a significant portion of the total diesel used today. Many companies Algenol and PowerFuel.de in USA and Germany, respectively, are producing algae-based oil to fulfil the demand of fossil fuel. Hence, implementation of new technologies and ideas are required in practice to increase more oil production which may promote the biodiesel production in future to replace existing fuel.

Production of biodiesel from microalgae involve many successive steps [38]: (i) Lipid-rich algal biomass production, harvesting and drying, (ii) Cell disruption and extraction of oil bodies (TAGs), and (iii) Transesterification. 


\subsubsection{Lipid-rich algal biomass production, harvesting and drying}

Microalgae can be harvested every day [3] in contrast to other food and non-food crops. Microalgae require $\mathrm{CO}_{2}$ as the one of the main utilizable element for aggrandizing its growth [39]. Microalgae have the capability to take $\mathrm{CO}_{2}$ from many sources such as industries with simultaneously abating its wicked effects [40]. Their water requirement can be met from wastewater from different antecedence as their growth substitute in media, with simultaneously treating it. Consequently, this can give cost effective outcome for oil production process from microalgae [41]. In addition to this microalgae require a particular wavelength of light energy for photosynthesis. Microalgae require light energy absorption at $700 \mathrm{~nm}$ and $680 \mathrm{~nm}$ in Photosystem II and Photosystem I, respectively. Both the quality and quantity of light are important for the production of biomass.

Thus, the production of the algal pool can be achieved by combining all criteria (water, $\mathrm{CO}_{2}$ and light). For the economic production of algae the open type systems such as raceway ponds as well as the closed type system such as photo-bioreactor, an advance machinery utilized in many counties especially in Australia, India, Israel, China, European Union and U.S. [42]. Closed type systems (photo bioreactor) are utilized more due to some advantages over open type system [43]. They require minimum area as in the case of photo-bioreactor $\left(5681 / \mathrm{m}^{2}\right)$ in contrast to open pond system requires high area $7828 / \mathrm{m}^{2}[11]$. High oil yield $\left(78.20 \mathrm{~m}^{3} / \mathrm{ha}\right.$ ) achieved in the case of the closed system due to high nutrients utilisation rate, while in the open pond system have $56.80 \mathrm{~m} 3 /$ ha oil yield [11]. The use of cell immobilization techniques and open ponds lead to low production of biomass due to lack of turbulence/mixing. Moreover, scale-up process is easier and maintained sophistically in the case of a closed system than open pond system. Chances of contamination from grazers and other protozoans, which eats up microalgae and causes reduction in their number is less in a closed system [44].

Hence, closed types of system or photobioreactors are assumed as more flexible and advantageous than open type systems and cell immobilization techniques for cultivation of microalgae. These systems also have some drawbacks such as oxygen accumulation and the cost of cultivation that need to be resolved.

In present scenario none of the existing systems seems as a promising candidate for pilot scale technology, so to overcome the drawbacks of existing systems there is an urgent urge for developing new technologies or approaches in this regard. The challenges taken up by 
scientists to overcome these negative repercussions include the usage of mass scale algal cultivation along with genetic/molecular engineering approaches.

Photo-bioreactor: A photo bioreactor is a glass unit, packed with all essential conditions needed for growth of biomass (Figure 2), which supports the growth of microbial cells including microalgae in an artificial atmosphere [45]. The extraction process of oil from algae biomass takes place in ionic liquid/nutrient media within reactor [46]. However, before running this kind of system, many aspects need to be optimized such as the balance between depth of culture (path length of light), turbulence and concentration of biomass for high productivity.

The prime demands for high yield in photo-bioreactor are turbulence or stirring, which provides the homogeneity within the culture by reducing the formation of biofilm and removal of oxygen that is continuously produced by algae after photosynthesis [47]. The balance between oxygen and $\mathrm{CO}_{2}$ concentration within the reactor is a very crucial condition for the growth of algae because the high concentration of oxygen in reactor starts photorespiration instead of photosynthesis by interfering the oxygenase activity of RuBisCo enzyme. Besides that high concentration of $\mathrm{O}_{2}$ in the reactor may also halt the nitrogen fixing ability of algae by inducing photooxidation and photoinhibition. Hence continuous supply of $\mathrm{CO}_{2}$ is very important with the elimination of $\mathrm{O}_{2}$ in the reactor for the sufficient growth of algal biomass.

High Productivity and cells density in the reactor are achieved at high turbulence because almost every cell gets the uniform stretch of exposure of nutrient in contrast of cell immobilization technique and open ponds. The high efficiency of reactor comes from high productivity, 2-4\% actual observed efficiencies of photo-bioreactors have been noticed with voluminous culture [44]. Hence, it can be concluded that closed type systems are more flexible than open type systems in terms of productivity and handling.

After growth of microalgae, another step involves harvesting of microalgae, which play an important role to achieve desired product. This can be achieved by various methods, which include sedimentation, centrifugation, filtration and flocculation. Here the following question arises: which method is most acceptable and applicable among all? Many researchers have analyzed different methods for harvesting of microalgae and concluded the following different opinions. For example, Pragyaa et al. [48] observed that sedimentation combined 
with flocculation is efficient among simple sedimentation, filtration and flocculation. Later, Young et al. [49] have experimentally proved that new modified nanoparticle engineering based method for microalgae cell harvesting is more efficient than sedimentation, filtration and flocculation.

Therefore, the key results of various studies have shown that the choice of harvesting method depends on the species of microalgae used for cultivation and cost criteria of energy extraction process.

After harvesting microalgae biomass the next step involves cell drying, which can be performed by various methods such as sun drying, freeze drying, lyophilization, heat/oven based drying, and spray drying. However, every method has its own advantages and disadvantages. For example, Mata et al. [50] have concluded that sun drying and drum drying are not effective and economical methods, respectively. On the other hand, heat or oven drying takes more energy input and lyophillization and freezing are considered as effective but costly methods.

Concas et al. [51] and Al-hattab et al. [52] explained the selection of the methods for cell harvesting and drying depends on various factors such as the types of species, maintenance of culture, time and re-utilization of media and suitability for industrial scale. The method suggested by Kim et al. [53] is based on chemicals (Fenton's reactant), which may or may not be the best possible in certain situations. Moreover, chemical-based methods appear to be good for scaling-up at industrial level and less energy consuming methods. The cost of the chemicals used in above-mentioned methods at industrial scale can be derived using the local costs of different chemicals such as ferrous sulphate heptahydrate (usually about US\$ 88105/ton) and hydrogen peroxide (usually about a US\$ 400-450/metric ton) which could vary in different part of the world.

In summary, it can be concluded that none of the methods is completely efficient for harvesting and drying of microalgal cell. There is currently a need to stimulate the development of new technologies and methods to perform microalgal cell harvesting and drying.

\subsubsection{Cell disruption and extraction of oil bodies}

Microalgal cell disruption for the release of oil bodies and cellular components can be done by several methods, including ultrasonic assisted method, press machine, chemical 
method, supercritical fluid, enzymatic method, microwave, autoclaving, bead beating, osmotic pressure method, soxhlet method and homogenizer. Cell disruption of microalgae seems as a very crucial step in biodiesel production process. Sometimes lipid extraction may fail due to improper cell disruption and selection of inappropriate lipid extraction method. So the main question arises here, that which cell disruption method is more appropriate and gives excellent results in cell blast? In the context of cell disruption, numerous studies have offered contrasting opinions. For example, Mata et al. [50] and JaeYon et al. [54] reported that microwave oven method is one of the simpler and powerful methods among autoclaving, osmotic shock and bead beating for microalgal cell explosion. Later, Prabakaran and Ravindran [55] observed ultrasonication as most efficient method among microwave, homogenizer and bead beating methods for microalgal cell disruption.

On the basis of already existing reviews and research papers, it can be concluded that currently available methods and technologies are not very efficient and standard for microalgal cell disruption. This needs further development of new cost-effective technologies and improvement in existing methods for efficient cell breaking.

After cellular breakdown process of microalgae, oil bodies and other cellular components are released into the environment that needs to be separated and extracted. Hence, the most common and applicable extraction method is solvent extraction method, which includes organic solvents such as hexane, dichloromethane, chloroform and toluene [56]. Two most commonly used solvents include chloroform and methanol among all for extraction of lipid are used by Folch et al. [57] and Bligh and Dyer [58]. These methods extract lipids incompletely, basically free fatty acids. It also extracts a significant amount of nonsaponifiable and non-nutritive material such as pigments. A number of new and advanced methods have been introduced by modifying existing methods for extraction of oil bodies from microalgae. For example, Ramluckana et al. [59] have used single, binary and more than two organic solvents at a time for extraction of oil bodies while Boutekedjiret et al. [60] presented the use of green bio-solvents (terpenes) extracted from aromatic plants.

\subsubsection{Transesterification}

TAGs or oil bodies have to undergo for transesterification to form biodiesel. Transesterification process comprises of methanolysis or ethanolysis in which the fatty acid methyl esters (FAMEs) forms. These are conjointly called biodiesel, produced by activation caused by either an acid or a base and attack by alcohol causes cleaving of an ester bond. The 
transesterification process requires catalysts, which can be acidic or alkaline in nature (Table 3). These catalysts have their own advantages and disadvantages. Acid catalysts can transesterify both complex lipids and free fatty acids, while basic catalyst cannot esterify free fatty acids. The problem associated with the acid catalyst is that it requires more reaction time than a basic catalyst with the additional requirement of heating [61]. To overcome these hurdles some complementary approaches are reported. For example, Lepage and Roy [62] used both acid and base catalyst together with alcohol. Later, Carrapiso and Garcia [61] used a combination of a basic catalyst in methanol, followed by an acid catalyst.

Transestrification reaction can also be performed with the use of hetrocatalysts [63] such as oxides of zinc and aluminum. The complex catalyst increases the overall cost of biodiesel production, and hence many counter scale up processes uses catalyst free and single step transesterification to lower down the process cost.

The efficient transesterification takes place in the absence of water because the presence of water mimics the rapidity of reaction [38, 63]. The presence of water moiety causes hydrolysis rather than esterfication, due to it high electron donating capacity than methanol or ethanol. Therefore, use of the dry sample or a water hunters such as 2,2-dimethoxypropane is added to avoid hindrance by water. Furthermore, pretreatment of lipid moiety for the presence of free fatty acids content is required as it may also slow down the reaction rate [38].

Transesterification is a crucial reaction to produce biodiesel from different resources including algae. This process plays an important role toward cost-effectiveness [64]; glycerin (more than $98 \%$ by weight of glycerol content) is a side product that is produced after transesterification process. This product is used by many industries as substrate or it can be recycled back to algae cultivation system to support growth.

\subsection{Oil content of microalgae}

Microalgae require an adequate amount of $\mathrm{CO}_{2}$ and proper intensity of light to provide the sufficient fruitage in the form of oil [42]. Microalgae have the highest efficiency to convert solar energy into biomass or chemical energy, which varies between 5.5 and $11.6 \%$ [63]. This energy conversion processes of microalgae help to fix $\mathrm{CO}_{2}$ into metabolites or oil. Earlier, investigators have suggested that algal-based oil in the conversion of solar 
energy into biomass is highest by at least one order of magnitude than other conventional crops based oil [67].

Other energy crops such as soybeans, palms, rapeseed or jatropha, produce 300-times lesser oil per hectare than algae [68]. Microalgae can yield 182,000 lit/ha oil annually [69]. Some species of microalgae can produce high oil than other crops as given in Table 4. Under stress conditions, oil yield can be increased up to $90 \%$ depending upon the species [11]. Another approach for enhancing oil production from microalgae is genetic and metabolic engineering at the molecular level. The molecular level engineering can be used probably to improve photosynthetic efficiency [70], intensify biomass production rate, modification in transcriptional factors associated with the enzymes involved in TAG synthesis pathway [71]. For example, in Chlamydomonas the nuclear and chloroplast genome engineering achieved by transforming a piece of DNA into microalgal genome through agrobacterium based vector and bombardment techniques [12]. In Cyclotella, upgraded activity of ACCase enzyme by up to 3-times is achieved for more lipid production by manipulating its genome [72]. Thus, algal-based oil exists as a compromising alternative which has the capability to replace petroleum-based fuels and fulfil the demand for existing fuels.

\subsection{Products of microalgae}

Microalgae are more promising and significant source of sustainable bioproducts [82] than other feedstocks (Table 5). These sustainable bioproducts include metabolites, which can be stored as their reserve food for periods of starvation. One of the most sophisticated metabolic products of microalgae is PUFAs and vitamins which are an essential fatty acid of human diet $[83,84]$ and used for therapeutic purposes. PUFAs have a different class of fatty acids, one of the important class among these are Omega-3 fatty acids. Fish oil has a high amount of PUFA content (omega-3 FA) [85], but the accretion of omega-3 fatty acids in Fishes take place by consuming microalgae in Aquaculture through diet transfer process. These omega-3 (PUFAs) fatty acids can also be included in the human diet directly from the microalgae. Many producer companies in the USA, China and Germany produce 3000 and 2000 t/year of Spirulina and Chlorella respectively in the form of powder and tablets as food supplements. Microalgae Chlorella (62.8 $\pm 2.5 \%)$ and Cadophora fracta $(50.9 \%)$ are known to have a good amount of PUFAs, [9] which is mainly used in feed industries or aquaculture. The other popular products of microalgae include glycerol produced parallel with biodiesel have more than 1500 known applications [15]. Some species of microalgae such as Nostoc 
and Hapalosiphon also used in the agricultural field as biofertilizer to promote growth. Thus, microalgae have reasonably more applicability in different industries due to their production of numerous value-added products.

\section{Are microalgae a solution to food versus fuel as well as land effect and environmental imbalance debates?}

The major issues raised due to the extraction of energy from energy crops include driving up food prices, deforestation and exertion of land resource [93]. The compelling chunks of the universe are now diverted from food to energy generation that leads to the grave in the food supply. Food and Agric. Org. (FAO) of United Nations estimated that more than 805 million people in the world are dropping due to appetite and dietary deficiency in the year of 2012-2014 [94]. In addition, the environmental imbalance is being created due to the continuous subsidence of drinking water and excessive use of pesticides and fertilizers on agricultural land.

Increase in ethanol production in the USA from corn was responsible for $1.2 \%$ points of the 43\% increase in world food prices during March 2007-2008 [95]. Also, International Monetary Fund characterized that half of the increases in the global food prices was due to biofuel production in 2007-2008. However, Rosegrant et al. [72] has estimated that the continuous biofuel demand contributed to $30 \%$ of the increase in maize prices between 2000 and 2007 as compare to earlier. Furthermore, they also reported that the universal increase of biofuel demand would lead the increase in the prize of wheat by $8-20 \%$, maize by $26-72 \%$ and sugar by $12-27 \%$ by the end of 2020 . Fischer et al. [96] reported that continuous expansion of biofuel would increase the prices of cereal and grains by $10 \%$ at the end of 2020.

In Malaysia, the production of palm-based biodiesel caused replacement of Borneo's jungle by palm plantations [93]. In the USA about $90 \%$ of bioethanol was produced from maize [97] and $23 \%$ of corn use to produce ethanol individually. Furthermore, about 92.9 million acres of corn was planted in 2007 , but $1 / 3^{\text {rd }}$ of it was used for bioethanol production which has caused abrupt rise (73\%) in the price of corn in 2007-2010 [93]. This continuous rise in food prices due to fuel production may be catastrophic in future and can affect food demand to the increasing population of the nation. 
Another problem associated with the biofuel production from energy crops are continuous shrinkage of cultivable land. Total cultivable land in Europe includes 164 million hectares out of which 76 million hectares are permanent grassland. In 2000, about 4.3 million hectares of cultivable land was diverted toward bioenergy producing crops which have initiated a debate in the country associated with the land effect and increased food prices.

In 1988-89, the total cropping land of India was 185.142 million hectare (mha) which fell by $2.76 \mathrm{mha}$ in the year 2008-09 [98]. In the year 2003-04, total cropping land was $183.19 \mathrm{mha}$ which fell by 0.80 mha to 182.39 mha in 2008-09 [98]. In 2010-11, total cropping land was left 182.00 mha, with an overall decrease of 406,000 hectares in between $2008-09$ to $2010-11$ (Figures 3 and 4). 20 out of the 29 states of India showed a decrease in cropping land in 2008-09, which was pegged at 790,000 ha [99]. Only five states of India (Gujarat, Manipur, Mizoram, J\& K and Arunachal Pradesh) showed the increase in cropping land at 384,000 ha in between 2008-09 and 2010-11 (Figures 3 and 4). Three states (Assam, Sikkim and Goa) showed no change in cropping land area. Gujarat [100] and Manipur had 6.13 and 0.354 mha agricultural land in 2008, these two states of India showed the highest increase 203,000 ha (3.31\% ) and 113,000 ha (3.19\%), respectively, in total cropping land in between 2008-09 and 2010-11 (Figures 3 and 4). Odisha and Haryana [101] had 6.18 and 3.7 mha in 2008; these two Indian states have shown a decrease of 260,000 ha (4.20\%) and 65,000 ha (1.76\%) in total cropping land in between the year 2008-09 to 2010-11 [99] (Figures 3 and 4). Uttar Pradesh, West Bengal, Punjab and Andhra Pradesh lost 0.208\%, 0.564\%, 0.33\% and 1.29\% of total cropping land between 2008-09 and 2010-11[102] (Figures 3 and 4). On the other hand, Jammu \& Kashmir, Mizoram and Arunachal showed an increase of 1.76\%, $0.427 \%$ and 0.00052\% in total cropping and between 2008-09 and 2010-11 (Figures 3 and 4).

To resolve the problem of shrinkage of land for non-agricultural purpose, the centre of the agricultural board in India, under its 2007 policy, has suggested the development of waste land utilization projects to save cultivable land for agriculture. Algae-based biofuel production projects have thus been suggested as a partial solution to this problem [103] because algae can be grown on wasteland with high salts concentration, dry land and nutrient death land.

Algae require less than $2-13 \%$ of total agricultural land for production of biofuel to compensate all petrol-based fuel demand than other fuel producing a crop (Figure 5). This does not compete with the utilization of chunk of land for the cultivation of food crops [94]. 
Added advantages include the increased fertility of infertile or less fertile soil after cultivation of algae for the purpose of other energy crops to grow.

In addition, one of the serious issues related to the other energy crops is an environmental imbalance which includes high toxic air amount, a high concentration of heavy metals in water bodies and food web etc [104]. Microalgae a renewable biomass feedstock which is considered as an environmental regulator in terms of carbon neutral energy production, also have the capability to maintain environmental balance, water balance and food web. For instance, Spirulina platens is a microalga has the highest capacity for removal of Cadmium from water [105] and other species of microalgae such as Scenedesmus quadricauda, Pseudochlorococcum typical are involved in the removal of mercury, cadmium and lead [106]. Bioaccumulation and biomagnifications of these toxic chemicals at tropic level cause damage to a number of enzymes and cause displacement of essential elements from proteins. Microalgae consume less drinking water or can use sea and waste water for production of energy in the form of biofuel than other energy based crops [5]. They also have efficient contaminant removal rate, which allows the treatment of waste water with simultaneous production of energy. The cost effective high rate algal ponds (HRAPs) developed for wastewater treatment [107] and removal of nutrient in the form of their biomass for energy extraction [108]. Microalgae can reduce carbon and toxicity in air at a high rate than other crops such as corn and switchgrass [109]. The $\mathrm{CO}_{2}$ liberated in algae-based fuel combustion process gets counterbalanced by the $\mathrm{CO}_{2}$ taken by the newly sowed ones to replace harvested ones (Figure 6). Moreover, microalgae require more fossil-based carbon to produce the same amount of bioenergy as other crops [109]. This quality makes microalgae efficient in capturing the carbon in the form of $\mathrm{CO}_{2}$ from other sources such as industries and power plants which help to save carbon credits [5]. Thus sequestration of carbon is high in case of microalgae than other terrestrial crops due to high $\mathrm{C}: \mathrm{N}$ ratio.

\section{Conclusions and future outlook}

The harmful environmental effects associated with fossil fuel combustion and its increasing prize due to high demand and limited availability are the global concern, which needs to be addressed by developing new technologies for the production of alternative fuel to fulfil growing demand for oil. To overcome these challenges, in contrast to other terrestrial plants the scientists have identified microalgae as an environment-friendly alternative to fulfil the demand of fossil fuel. This review article describes different energy components such as lipids, oil and other sustainable products of microalgae for the future world. In terms of its 
potential, microalgae produces greater amount (over 300-times than other energy crops) of biofuel, which could fulfil the growing international demand for fossil fuel. In addition, microalgae seems a viable, economic and cost effective alternative than other energy crops through its contribution in a multifunctional way, e.g., treatment of waste water, mitigation of $\mathrm{CO}_{2}$ and energy delivery. The multipurpose usage of microalgae for production of biofuel / energy may support the socioeconomic welfare of growing population. Summary of the key benefits of microalgae along with respective application areas is provided in Table 6.

Microalgae have the capability to produce bio-sustainable products, which do not appear to compromise on human's right to food, water and health and do not disturb the environmental resources. The large-scale production of energy in the form of fuel from other existing resources such as Jatropha plantations in developing countries is infringing the rights of local farmers, farm workers, landholders and vulnerable populations. Regional production of microalgae and processing into oil and other valuable products may provide economic benefits to rural communities in terms of value added chain. Moreover, if the algae-based energy production continues to blossom around the globe, the agricultural sector would remain unaffected because algae production neither require cultivable land nor the fresh water resources.

The microalgae-based products have potential to emerge as the future resource for number of industries such as automotive, pharmaceutical (antibacterial, antibiotics, peptides and cytokines etc.) biotechnology, nanotechnology (carrageenan, algae-based silicon chips), feed industry (algal meals, fish feeds or animal feeds), energy (bioethanol and biodiesel), chemical (aligns, agar) and food industries such as protein-rich food products. Thus, the utilization of algae for energy extraction may emerge in the form of increased human developmental index (HDI) due to its positive impacts on human food and nutrition, health products, employment and monetary value. This is also expected to enhance the sustainable environmental impact through optimum land and water utilization for generation of renewable energy.

The key conclusions drawn from this review are as follows:

- Microalgae have become main economically feasible microorganism to fulfil the demand of petrol-based fuels with minimum impact on land, drinking water and the environment.

- The use of microalgae for multifunctional large spectrum biorefinery products delivery along with the recycling of waste and raw materials result in a cost-effective and zero waste production outcomes which causes less pollution. 
- Microalgae help to maintain food chain, conservation of land and water resources. This also results in sequestration of $\mathrm{CO}_{2}$ and treatment of waste water, which puts less stress on the agricultural land use, drinking water utilization and the environment.

- The successful collaboration of new technologies is likely to accelerate the usage of algae for research and development which may fulfil the main objective of developing countries by the availability of fuel at low cost with the establishment of a number of industries and job creation.

In contrast to the potential benefits listed as above, it is felt that future efforts would be required to overcome the cost and disadvantages related to the existing systems for small and large-scale production of microalgae. It might be solved with the integration of sequestration of $\mathrm{CO}_{2}$ from industries and use of waste water, fertilizers and recycling of the produced waste. Furthermore, cheaper systems with recycling facilities, automatic control and minimum labor could be designed for this purpose. Advancement in technologies for microalgal cell drying, harvesting and disruption is also required for efficient biodiesel and energy extraction. We have already mentioned in different sections / subsections that existing approaches are not very simple, efficient and inexpensive, which prompt to have new hypothetical ideas related to cell drying harvesting and disruption. For example, the simple and hypothetical approach related to cell drying may include the construction of wooden box supplied with hot air, which may give some economically feasible results in future. This may resolve the problems associated with other existing methods such as sun drying which is the most simple and inexpensive method but has certain limitations, such as it results in deterioration of cell components. However, Kim et al. [53] have observed the cell harvesting and disruption can be achieved with the use of chemicals which can give more than $99 \%$ of cell harvesting and disruption efficiency. As argued by Concas et al. [51] and Al-hattab et al. [52] the selection of the methods for cell harvesting and drying depends on a variety of factors such as the types of species, maintenance of culture, time and re-utilization of media and suitability for industrial scale.

Extensive research using the new technologies such as genetic engineering and media engineering may result in significant increase of the yield of microalgae in the form of biofuels and other energy products. Ultimately, this may lay a foundation to establish a number of industries for its large scale production, extraction and processing, which could play an important role in the socio-economic development of developing countries and emerging economies such as India. 


\section{Acknowledgements}

The authors thank the Ministry of Human Resource Development, Government of India and Indian institute of Technology Roorkee (India) for providing research fellowship to Richa Katiyar. The authors also thank the anonymous reviewers for their valuable time and comments to improve the quality of this review article.

\section{References}

[1]. Tabatabaei M, Tohidfar M, Jouzani GS, Safarnejad M, Pazouki M. Biodiesel production from genetically engineered microalgae: Future of bioenergy in Iran. Renewable and Sustainable Energy Reviews 2011; 15; 1918-1927.

[2]. Xu H, Miao X, and Wu Q. High quality biodiesel production from a micro alga Chlorella protothecoides by Heterotrophic Growth in Fermenters. Journal of Biotechnology 2006; 126, 499-507.

[3]. Minowa T, Yokoyama SY, Kishimoto M, Okakurat T. Oil production from algal cells of Dunaliella tertiolecta by direct thermochemical liquefaction. Fuel 1995; 74, 1735-1738.

[4]. Shurin J, Mandal S and Abbott RL. Trait diversity enhances yield in algal biofuel assemblages. Applied Ecology 2014; 51; 603-611.

[5]. Haag AL. Algae Bloom Again. Nature 2007; 447; 520-521.

[6]. Ghosha A, Khanraa S, Mondalb M., Halderb G, Tiwari NO, Sainid S, Bhowmicke KT, Gayena K. A Review- Progress toward isolation of strains and genetically engineered strains of microalgae for production of biofuel and other value added chemical. Energy Conversion and Management 2016; 113; 104-118.

[7]. Teresa LDS, Gouveia L, Reis A. Integrated microbial processes for biofuels and high value-added products the way to improve the cost effectiveness of biofuel production. Applied Microbiology and Biotechnology 2014; 98;1043-1053.

[8]. Wenguang Z, Paul C, Min Min X, Ma J, Wang R, Griffith F, Hussain P, Peng Q, Xie Y, Li J, Shi J, Meng RR. Renewable and Sustainable Energy Reviews 2014; 36; 256-269.

[9]. Demirbas A and Fatih Demirbas M. Algae as a New Source of Biodiesel. A book- Algae. Energy; 2010; chapter 6; p-146. 
[10]. Metz B, Davidson OR, Bosch PR, Dave R, Meyer LA. Contribution of Working Group III to the Fourth Assessment Report of the Intergovernmental Panel on Climate Change, United Kingdom and New York, USA. Cambridge University Press, Cambridge 2007.

[11]. Chisti Y. Biodiesel from microalgae. Biotechnology Advances 2007; 25; 294-306.

[12]. Kumar SV, Misquitta RW, Reddy VS, Rao BJ, Rajam MV. Genetic transformation of the green alga Chlamydomonas reinhardtii by Agrobacterium tumefaciens. Plant Science $2004 ; 166 ; 731-8$.

[13]. Green car congress (GCC), 2015. http://www.greencarcongress.com. [Accessed; 13.02.2016].

[14]. He P, ZengY, Du D, Lin JY, Wang Y, Abdel-Fattah IA. A review of novel materials and technologies for the sustainable development of microalgae biofuel. Social Science Research Network 2016; 1-30.

[15]. Liandong Z. Biorefinery as a promising approach to promote microalgae industry: An innovative framework. Renewable and Sustainable Energy Reviews 2015; 41; 1376-1384.

[16]. Satyanarayana KG, Mariano AB and Vargas JVC. A review: microalgae a versatile source for sustainable energy and materials. International Journal of Energy Research 2011; $35 ; 291-311$.

[17]. Becker EW. Microalgae Biotechnology and Microbiology, Cambridge: Cambridge University Press 1994; 177-195.

[18]. Demirbas A and Fatih Demirbas M. Importance of algae oil as a source of biodiesel. Energy Conversion and Management 2011; 52; 163-170.

[19]. Griffiths MJ, Harrison STL. Lipid productivity as a key characteristic for choosing algal species for biodiesel production. Applied Phycology 2009; 21; 493-507.

[20]. Li Y, Han D, Sommerfeld M, Hu Q. Photosynthetic carbon partitioning and lipid production in the oleaginous microalga Pseudochlorococcum sp. (Chlorophyceae) under nitrogen- limited conditions. Bioresource Technology 2010 (c); 102; 123-9.

[21]. Wu YQ, Yu Y, Hu YH, Potential biomass yield per phosphorus and lipid accumulation property of seven microalgal species. Bioresource Technology 2012; 130C; 599-602. 
[22]. Liu YZ, Wang CG, Cheng Z, Effect of Iron on Growth and Lipid Accumulation in Chlorella vulgaris. Bioresource Technology 2008; 99; 4717-22.

[23]. Rao AR, Dayananda C, Sarada R, Shamala TR, Ravishankar G.A. Effect of salinity on growth of green alga Botryococcus braunii and its constituents, Bioresource Technology 2007; 98; 560-564.

[24]. Weldy CS and Huesemann M. Lipid production by Dunaliella salina in batch culture: effects of nitrogen limitation and light intensity. U.S. Department of Energy, Undergrad Research 2007; 7; 115-122.

[25]. Miao X, and Wu Q. High yield bio-oil production from fast pyrolysis by metabolic controlling of Chlorella protothecoides. Journal of Biotechnology 2004; 110; 85-93.

[26]. Subramaniam R, Dufreche S, Zappi M, Bajpai R. Microbial lipids from renewable resources: production and characterization. Journal of Industrial Microbiology and Biotechnology 2010; 37; 1271-1287.

[27]. Mandal S and Mallick N. Microalga Scenedesmus obliquus as a potential source for biodiesel production. Applied Microbiology Biotechnology 2009; 84; 281-291.

[28]. Hansen CE and Rossi P. Effects of culture conditions on accumulation of arachidonic and eicosapentaenoic acids in cultured cells of Rhytidzadelphus squarrosus and Eurhynchzum strzatum. Phytochemistry 1991; 30; 1837-1841.

[29]. Geider RJ, LaRoche J, Greene R, Molaizola M. Response of the photosynthetic apparatus of Phaeodactylum tricornutum to nitrate, phosphate or iron starvation, Phycol. $1993 ; 29 ; 755-766$.

[30]. Yu ET, Zendejas FJ, Lane PD, Gaucher S, Simmons BA, Lane TW. Triacylglycerol accumulation and profiling in the model diatoms Thalassiosira pseudonana and Phaeodactylum tricornutum (Baccilariophyceae) during starvation, Applied Phycology 2009; $21 ; 669-681$.

[31]. Wenhua L, Zhongwen H, Ping L, Jinfeng X, Bin C. Formation of triacylglycerol in Nitzschia closterium f. minutissima under nitrogen limitation and possible physiological and biochemical mechanisms. Journal of Experimental Marine Biology and Ecology 2012; 418$419 ; 24-29$. 
[32]. Chokshia K, Panchaa I, Trivedib K, Georgea B., Mauryaa R, Ghoshb A, Mishraa S. Biofuel potential of the newly isolated microalgae Acutodesmus dimorphus under temperature induced oxidative stress conditions. Bioresource Technology 2015; 180; 162171.

[33]. Lowrey J, Brooks SM, McGinn JP. A critical review- Heterotrophic and mixotrophic cultivation of microalgae for biodiesel production in agricultural wastewaters and associated challenges. Journal of Applied Phycology 2015; 27; 1485-1498.

[34]. Hildebrand M, Davis AK, Smith RS, Traller CJ, Abbriano R. A review: The place of diatoms in the biofuels industry. Biofuels 2012; 3; 221-240.

[35]. Hildebrand M, Davis AK, Smith RS, Traller CJ, Abbriano R. A review: The place of diatoms in the biofuels industry. Biofuels 2012; 3; 221-240.

[36]. Worldwatch institute (WWI), vision for sustainable world, worldwatch@worldwatch.org. 1400 16th St. NW, Ste. 430, Washington, DC 20036 (202); 2013; 745-8092.

[37]. Ahmad AL, Mat Yasin NH, Derek CJC, Lim JK. A review -Microalgae as a sustainable energy source for biodiesel production. Renewable and Sustainable Energy Reviews 2011; 15, 584-593.

[38]. Sing SF, Isdepsky A, Borowitzka MA, Moheimani NR. Production of biofuels from microalgae. Mitigation and Adaptation Strategies for Global Change 2013; 18; 47-72.

[39]. Kishimoto M, Okakura T, Nagashima H, Minowa T, Yokoyama SY, Yamaberi K. CO2 fixation and oil production using micro-algae. Journal of Fermentation and Bioengineering $1994 ; 78 ; 479-482$.

[40]. Huntley M and Redalje D. A new appraisal: CO2 mitigation and renewable oil from photosynthetic microbes. Mitigation and Adaptation Strategies for Global Change 2007; 12, $573-608$.

[41]. Bajhaiya AK, Mandotra SK, Suseela MR, Kiran T, Ranade S. Algal biodiesel: the next generation biofuel for India. Asian Journal of Experimental Biological Sciences 2010; 1; 728739. 
[42]. Chaumont D. Biotechnology of algal biomass production: a review of systems for outdoor mass culture. Applied Phycology 2005; 5; 593-604.

[43]. Jorquera O, Kiperstock A, Sales EA, Embirucu M, Ghirardi ML Comparative energy life-cycle analyses of microalgal biomass production in open ponds and photobioreactors. Bioresource Technology 2010; 101; 1406-1413.

[44]. Del Campo JA, Rodríguez H, Moreno J, Vargas MA, Rivas J, Guerrero MG. Lutein production by Muriellopsis sp. in an outdoor tubular photobioreactor. Journal of Biotechnol $2001 ; 85 ; 289-295$.

[45]. Sharma YC, Singh B, Upadhyay SN. A review- Advancement in development and characterization of biodiesel. Fuel 2008; 87; 2355-2373.

[46]. Teixeira RE. Energy-efficient extraction of fuel and chemical feedstocks from algae. Green Chemistry 2012; 14 (2); 419-427.

[47]. Grobbelaar JU, Nedbal L, Tichy V. Influence of high frequency light/dark fluctuations on photosynthetic characteristics of microalgae photo acclimated to different light intensities and implications for mass algal cultivation. Applied Phycology 1996; 8; 335-343.

[48]. Pragyaa N, Pandeya KK, Sahoo PK. A review on harvesting, oil extraction and biofuels production technologies from microalgae. Renewable and Sustainable Energy Reviews 2013; $24 ; 159-171$.

[49]. Young LC, Kyubock L, You-Kwan O. A review-Recent nanoparticle engineering advances in microalgal cultivation and harvesting processes of biodiesel production. Bioresource Technology 2015; 184; 63-72.

[50]. Mata Teresa M, Antonio Martins A, Nidia Caetano S. A review: Microalgae for biodiesel production and other applications. Renewable and Sustainable, Energy Reviews $2010 ; 14 ; 217-232$.

[51]. Concas A, Pisua M, Caoa G. Micro algal cell disruption through fenton reaction: experiments, modeling and remarks on its effect on the extracted lipids composition. Chemical Engineering Transactions 2015; 43; 367-372. 
[52]. Al-hattab M, Ghaly A, Hammoud A. Microalgae Harvesting Methods for Industrial Production of Biodiesel: Critical Review and Comparative Analysis. Journal of Fundamentals of Renewable Energy 2015; 5; 154.

[53]. Kim DY, Oh YK, Park JY, Kim B, Choi SA, Han JI. An integrated process for microalgae harvesting and cell disruption by the use of ferric ions. Bioresource Technology $2015 ; 191 ; 469-74$.

[54]. Jae-Yon L, Chan Y, So-Young J, Chi-Yong A, Hee-Mock O. Comparison of several methods for effective lipid extraction from microalgae. Bioresource Technology 2010; 101; S75-S77.

[55]. Prabakaran P and Ravindran AD. A comparative study on effective cell disruption methods for lipid extraction from microalgae. Lett Applied Microbiology 2011; 53; 150-154.

[56]. Mubaraka M, Shaijaa A, Suchithrab TV. A review- The extraction of lipid from microalgae for biodiesel production. Algal Research 2015; 7; 117-123.

[57]. Folch J, Lees M, Sloane Stanley GH. A simple method for the isolation and purification of total lipids from animal tissues. Biological Chemistry 1957; 226; 497-509.

[58]. Bligh EG and Dyer WJ. A rapid method of total lipid extraction and purification. Biochemistry and Physiology 1959; 8; 911-917.

[59]. Ramluckana K, Moodleya GK, Bux F. An evaluation of the efficacy of using selected solvents for the extraction of lipids from algal biomass by the soxhlet extraction method. Fuel $2014 ; 116 ; 103-108$.

[60]. Boutekedjiret C, Vian MA, Chemat F. Terpenes as green solvents for natural products extraction. Alternative Solvents for Natural Products Extraction Green Chemistry and Sustainable Technology 2014; 205-219.

[61]. Carrapiso AI and Garcia C. Development in lipid analysis: some new extraction techniques and in situ transesterification. Lipids 2000; 11; 1167-1177.

[62]. Heaton EA, Flavell RB, Mascia PN, Thomas SR, Dohleman FG, Long SP. Herbaceous energy crop development: recent progress and future prospects. Current Opinions in Biotechnology 2008b; 19; 202-209. 
[63]. Park JY, Park MS, Lee YC, Yang JW. Advances in direct transesterification of algal oils from wet biomass. Bioresource Technology 2015; 184; 267-75.

[64]. Gonçalves, LA, Pires, CMJ, Simões, M, Biotechnological potential of Synechocystis salina co-cultures with selected microalgae and cyanobacteria: Nutrients removal, biomass and lipid production. Bioresource Technology 2016; 200; 279-286.

[65]. Meher LC, Vidya Sagar D, Naik SN. A review: Technical aspects of biodiesel production by transesterification. Renewable Sustainable Energy Reviews 2006; 10; $248-$ 268.

[66]. Sing SF, Isdepsky A, Borowitzka MA, Moheimani NR. Production of biofuels from microalga. Mitigation and Adaptation Strategies for Global Change 2013; 18; 47-72.

[67]. Groom MJ, Gray EM, Townsend P.A. Biofuels and biodiversity: principles for creating better policies for biofuel production. Conservation Biology 2008; 22; 602-609.

[68]. Gahukar RT. New sources of feed stocks for biofuels production: Indian perspectives. Journal of Petroleum Technology and Alternative Fuels 2012; 3; 24-28.

[69]. Reijnders L. Do biofuels from microalgae beat biofuels from terrestrial plants? Trends in Biotechnology 2008; 26; 349-350.

[70]. Victoria HW, Sarah DA, Radakovits R, Jinkerson RE, Posewitz MC. Improving photosynthesis and metabolic networks for the competitive production of phototroph-derived biofuels, Current Opinion in Biotechnology 2012; 23; 290-297.

[71]. Grotewold E. Transcription factors for predictive plant metabolic engineering. Current Opinion in Biotechnology 2008; 19; 138-44.

[72]. Rosegrant MW, Zhu T, Msangi S, Sulser T. Global Scenarios for Biofuels: Impacts and Implications. Review of Agricultural Economics 2008a; 30; 495-505.

[73]. Ben Amotz A and Tornabene, TG. Chemical profile of selected species of macroalgae with emphasis on lipids. Phycol 1985; 21; 72-81.

[74]. Banerjee A, Sharma R, Chisti Y, Banerjee UC. Botryococcus braunii: a renewable source of hydrocarbons and other chemicals. Critical Reviews in Biotechnology 2002; 22; 245-79. 
[75]. Metzger P and Largeau C. Botryococcus braunii: a rich source for hydrocarbons and related ether lipids. Applied Microbiology and Biotechnology 2005; 66; 486-96.

[76]. Sheehan J, Dunahay T, Beneman J, Roessler P. A look back at the US Department of Energy's Aquatic Species Program- biodiesel from algae. National Renewable Energy Laboratory (NREL) report: NREL/TP-580-24190, Golden, CO; 1998.

[77]. Tsukahara K and Sawayama S. Liquid fuel production using microalgae. Journal of Japanese Petroleum Institute 2005; 48, 251-9.

[78]. Brown MR, Dunstan GA, Norwood SJ, Miller KA. Effects of harvested stage and light on the biochemical composition of the diatom Thalassiosira pseudonana. Phycol 1996; 32; $64-73$.

[79]. Muthukumar A, Elayaraja S, Ajithkumar TT, Kumaresan S, Balasubramanian T. Biodiesel production from marine microalgae Chlorella marina and Nannochloropsis salina. Journal of Petroleum Technology and Alternative Fuels 2012; 3(5); 58-62.

[80]. Subramaniam R, Dufreche S, Zappi M, Bajpai R. Microbial lipids from renewable resources: production and characterization. Industrial Microbiology and Biotechnology 2010; $37 ; 1271-1287$.

[82]. Rekha VR, Gurusami P, Santhanam A, Devi S, Ananth S. Culture and Biofuel Production efficiency of Marine Microalgae Chlorella Marina and Skeletonema Costatum. Indian Journal of Geo-Marine Science 2012; 41; 152-158.

[82]. Qiang H, Sommerfeld M, Jarvis E, Ghirardi M, Posewitz M, Seibert M, Darzins A. Microalgal triacylglycerols as feedstocks for Biofuel production: perspectives and advances. The Plant Journal 2008; 54; 621-639.

[83]. Ghosh A, Khanra S, Mondal M, Halder G, Tiwari ON, Saini S, Bhowmicke TK, Kalyan G. A review- Progress toward isolation of strains and genetically engineered strains of microalgae for production of biofuel and other value added chemicals. Energy Conversion and Management 2016; 113; 104-118.

[84]. Cardozo KHM, Guaratini T, Barros MP, Falcao VR, Tonon AP, Lopes NP, Campos Sara TMA, Souza AO, Colepicolo Pio PE. A review: Metabolites from algae with economical impact. Comparative Biochemistry and Physiology 2007; 146(C); 60-78. 
[85]. Vazhappilly $\mathrm{R}$ and Chen F. Heterotrophic production potential of omega-3 polyunsaturated fatty acids by microalgae and algae-like microorganisms. Botanica Marina $1998 ; 41 ; 553-8$.

[86]. Aust O, Stahl W, Sies H, Tronnier H, Heinrich U. Supplementationwith tomato-based products increases lycopene, phytofluene, and phytoene levels in human serum and protects against UV-light-induced erythema. International Journal for Vitamins and Nutrition Research 2005; 75; 54-60.

[87]. Mayer AMS and Hamann MT. Marine pharmacology in 2001-2002: marine compounds with anthelmintic, antibacterial, anticoagulant, antidiabetic, antifungal, anti-inflammatory, antimalarial, antiplatelet, antiprotozoal, antituberculosis, and antiviral activities; affecting the cardiovascular, immune and nervous systems and other miscellaneous mechanisms of action, Comparitive Biochemistry and Physiology 2005; 140; 265-286.

[88]. Andrade LR, Salgado LT, Farina M, Pereira MS, Mourao PAS, Amado-Filho GM. Ultrastructure of acidic polysaccharides from the cell walls of brown algae, Structural Biology 2004; 145; 216-225.

[89]. Bandaranayake WM. Mycosporines: are they nature's sunscreens? Nat. Prod. Rep. $1998 ; 15 ; 159-172$.

[90]. Demirbas A. Progress and recent trends in biodiesel fuels. Energy Conversion and Management 2009; 50; 14-34.

[91]. Dos Santos MD, Guaratini T, Lopes JLC, Colepicolo P, Lopes NP. Plant cell and microalgae culture. In: Modern Biotechnology in Medicinal Chemistry and Industry. Research Signpost, Kerala, India 2005.

[92]. Kujbida P, Hatanaka E, Campa A, Colepicolo P, Pinto E. Effects of microcystins on human polymorphonuclear leukocytes, Biochemistry Biophysics Research Community 2006; $341 ; 273-277$.

[93]. Duncan GR. Beyond food versus fuel. Nature 2011; 474; 6-8.

[94]. Schenk PM, Thomas-Hall SR, Stephens E, Marx UC, Mussgnug JH, Posten C, Kruse O, Hankamer B. Second generation biofuels: high-efficiency microalgae for biodiesel production. Bioenergy Research 2008; 1; 20-43. 
[95]. Lazear EP. Testimony to the U.S. Senate foreign relations committee, Washington, D.C. 2008.http://georgewbush-whitehouse.archives.gov/cea/lazear20080514.html. [Accessed 28.06.2014].

[96]. Fischer G, Hizsnyik E, Prieler S, Shah M, Velthuizen H V. Biofuels and Food Security, OPEC Fund for International Development 2009.

[97]. De Oliveira MED, Vaughan BE, Rykiel EJ. Ethanol as fuel: Energy, carbon dioxide balances, and ecological footprint. Bioscience 2005; 55; 593-602.

[98]. Sharad Pawar. Agri land shrinks by $2.76 \mathrm{mn}$ hectare in last 2 decades. The Economic times 2011. Agriculture. http://articles.economictimes.indiatimes.com/ [Accessed on 20/July/2016].

[99]. Mohan V. Cultivable land continues to shrink. The Times of India 2013; p-7.

[100]. Swain M, Kalamkar SS, Kapadia MK. State of Gujarat Agriculture 2011-12, AERC Report 2012; 146; 19.

[101]. Haryana development report. Planning commission govt. of India New Delhi, 2009. Pp-39. http://planningcommission.nic.in/plans/stateplan/sdr/sdr_haryana1909.pdf [Accessed on $20 / \mathrm{July} / 2016]$.

[102]. Department of Agriculture Government of Uttar Pradesh, A report- Rashtriya Krishi Vikas Yojana Eleventh Five Year Plan (2007-12), prepared by Agricultural finance corporation Ltd. pp-22-23 http://agriculture.up.nic.in/

[103]. Singh A, Nigam PS, and Murphy JD. Renewable fuels from algae: an answer to debatable land based fuels. Bioresource Technology 2011; 102; 10-16.

[104]. Ghadiryanfara M, Rosentraterb AK, Keyhanic A, Omidc M. A review- Macroalgae production, with potential applications in biofuels and bioenergy. Renewable and Sustainable Energy Reviews. 2016; 54; 473-481.

[105]. Zhou JL, Huangb PL, Lin RG. Sorption and desorption of $\mathrm{Cu}$ and $\mathrm{Cd}$ by macroalgae and microalgae. Environmental Pollution 1998; 101; 67-75.

[106]. Shanab SEA and Shalaby E. Bioremoval capacity of three heavy metals by some microalgae species (Egyptian Isolates). Plant Signalling and Behaviour 2012; 7(3); 1-8. 
[107]. Abinandan S and Shanthakumar S. A review- Challenges and opportunities in application of microalgae (Chlorophyta) for wastewater treatment. Renewable and Sustainable Energy Reviews 2015; 52; 123-132.

[108]. Sutherlanda DL, Howard-Williamsa C, Turnbullb MH, Broady PA, Craggsc RJ. Enhancing microalgal photosynthesis and productivity in wastewater treatment high rate algal ponds for biofuel production. Bioresource Technology 2014; 184; 222-229.

[109]. Clarens AF, Resurreccion EP, White MA, Colosi LM. Environmental Life Cycle Comparison of Algae to Other Bioenergy Feedstocks. Environmental Science and Technology 2010; 44; 1813-1819.

[110]. Wenguang Z. Potential Applications of Microalgae inWastewater Treatments, Recent Advances in Microalgal Biotechnology, OMICS E book 2014; 1-9.

[111]. Ragauskas AJ, Williams CK, Davison BH, Britovsek G, Cairney J, Eckert CA. A path forward for biofuels and biomaterials. Science 2006; 311, 484-9. 
Figures with captions

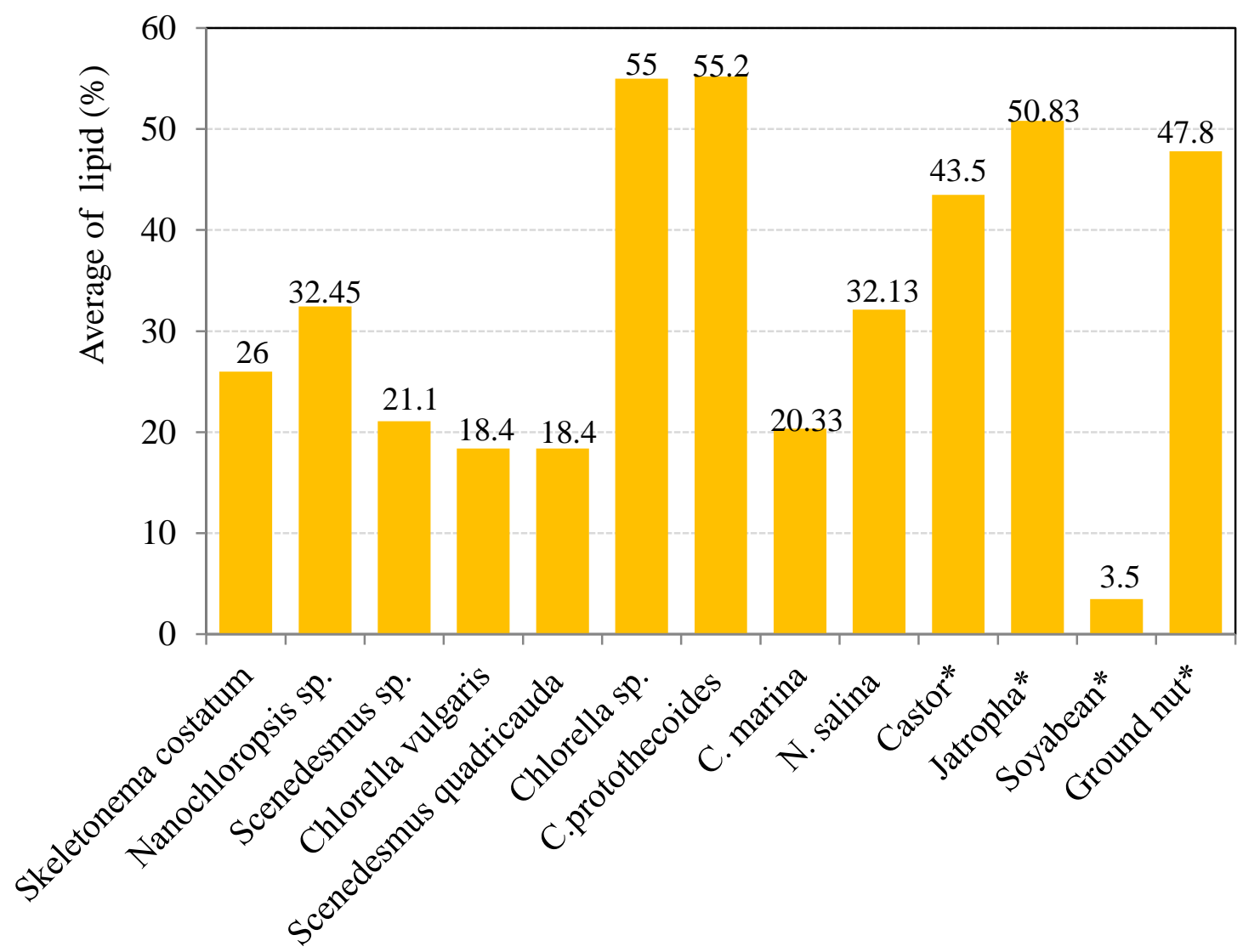

Figure 1. Average lipid percentage of dry weight of different microalgae species in contrast of some terrestrial plants*. 


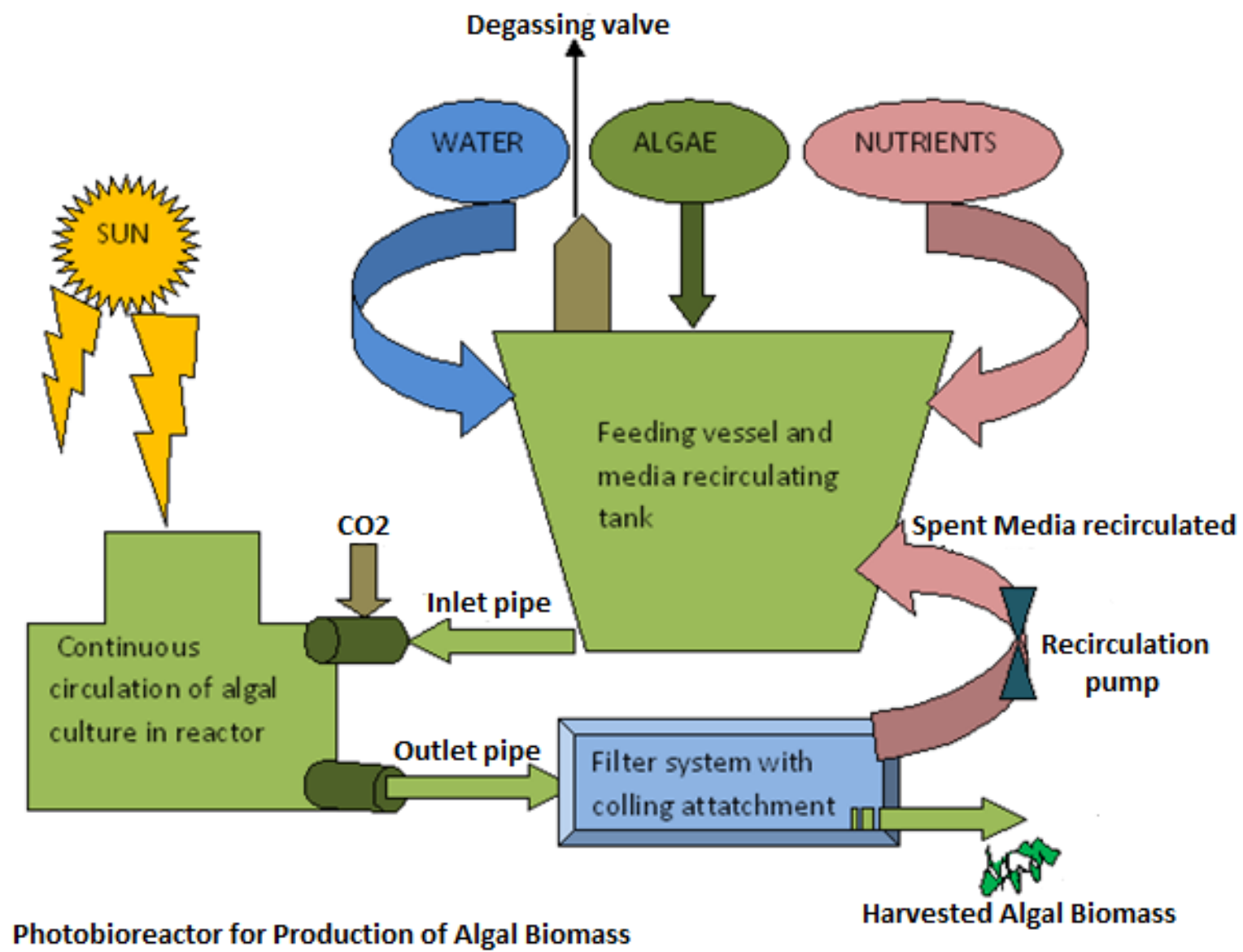

Figure 2. A design of photo-bioreactor for production of algal biomass. 


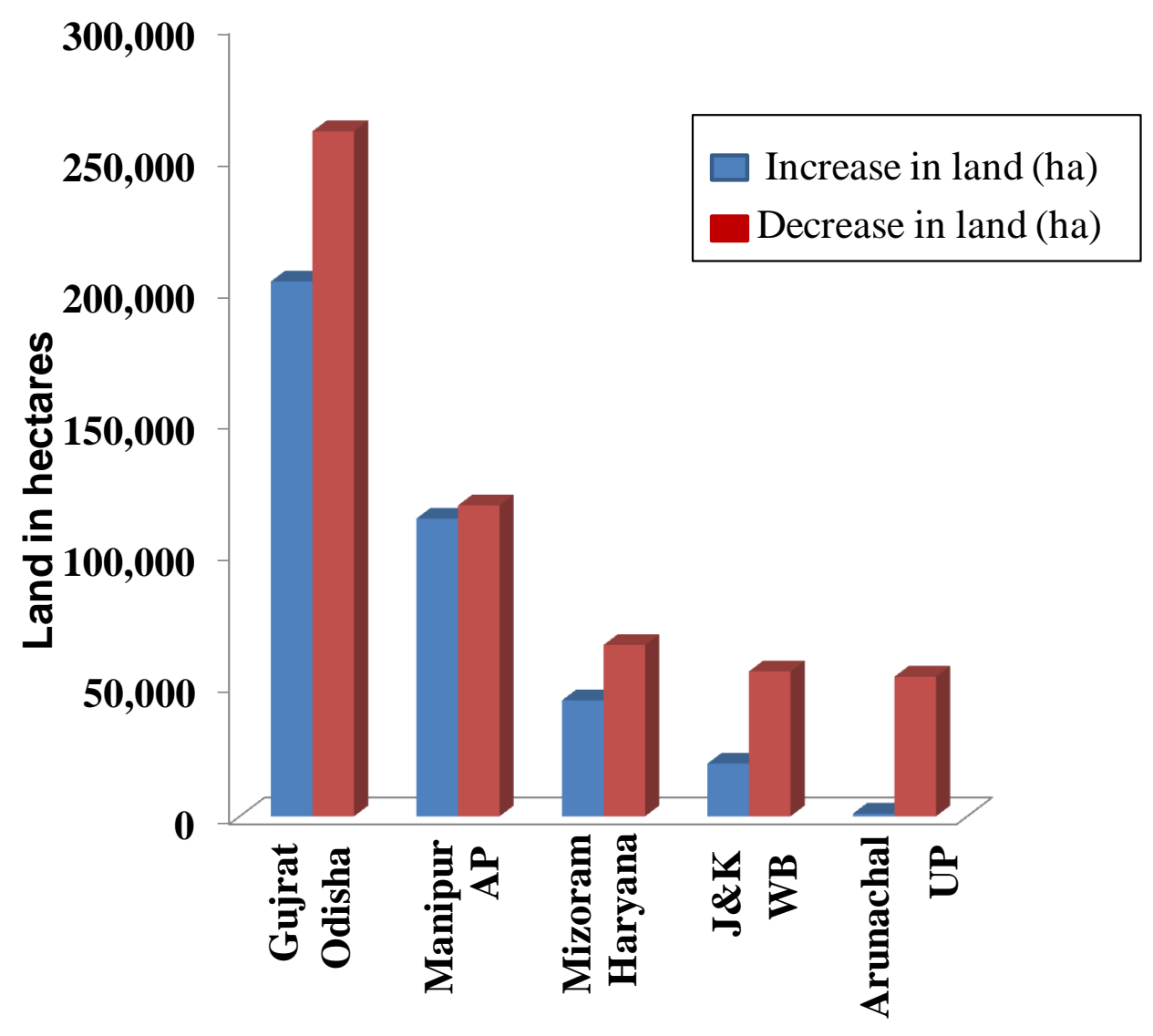

Figure 3. States of India showing decrease and increase in total agricultural land (hectares) for nonagricultural purposes during the year of 2007-08 to 2010-11. 


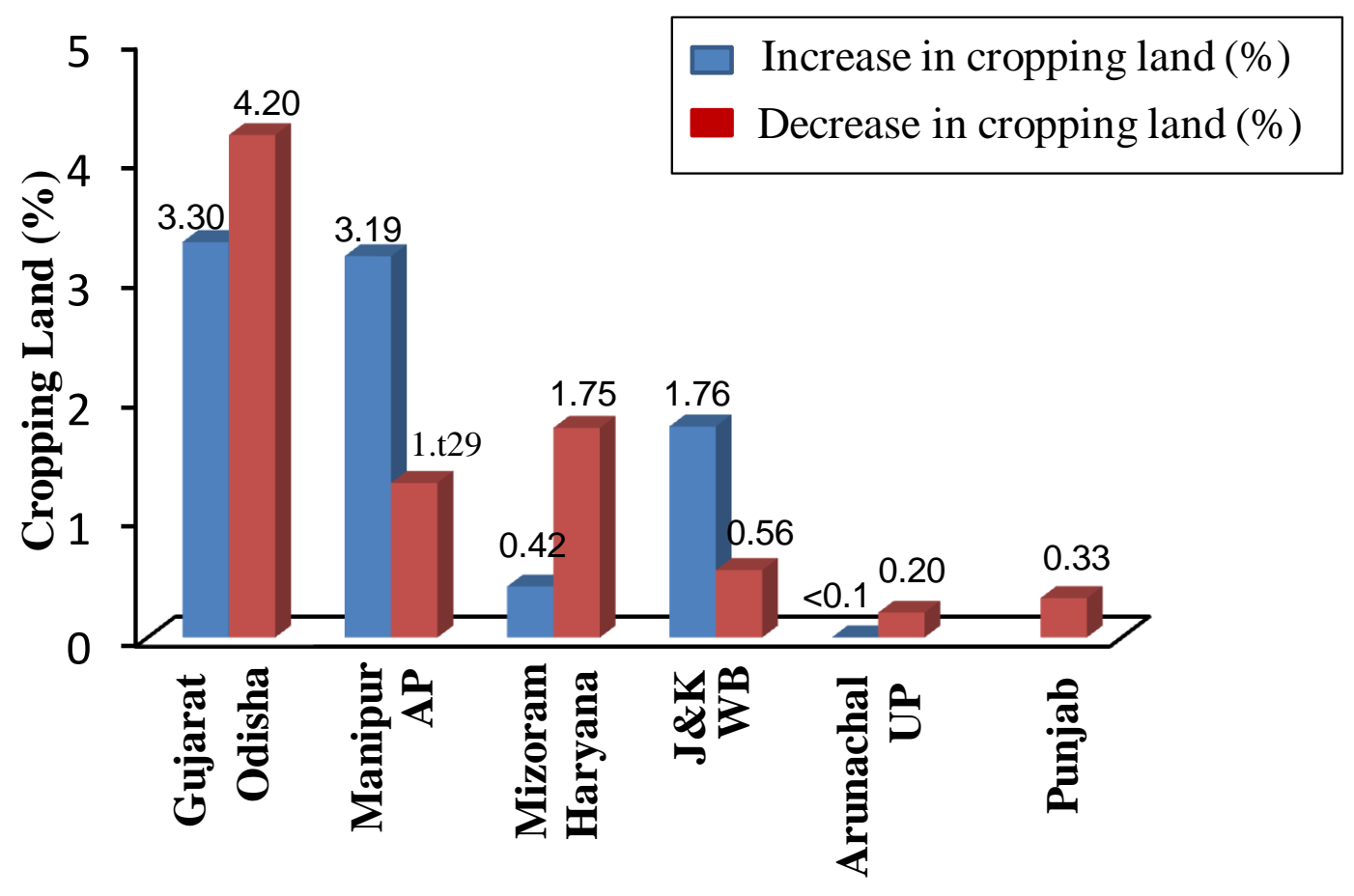

Figure 4. The States of India showing the percentage of decrease and increase in total agricultural land for nonagricultural purposes during the year of 2007-08 to 2010-11. 


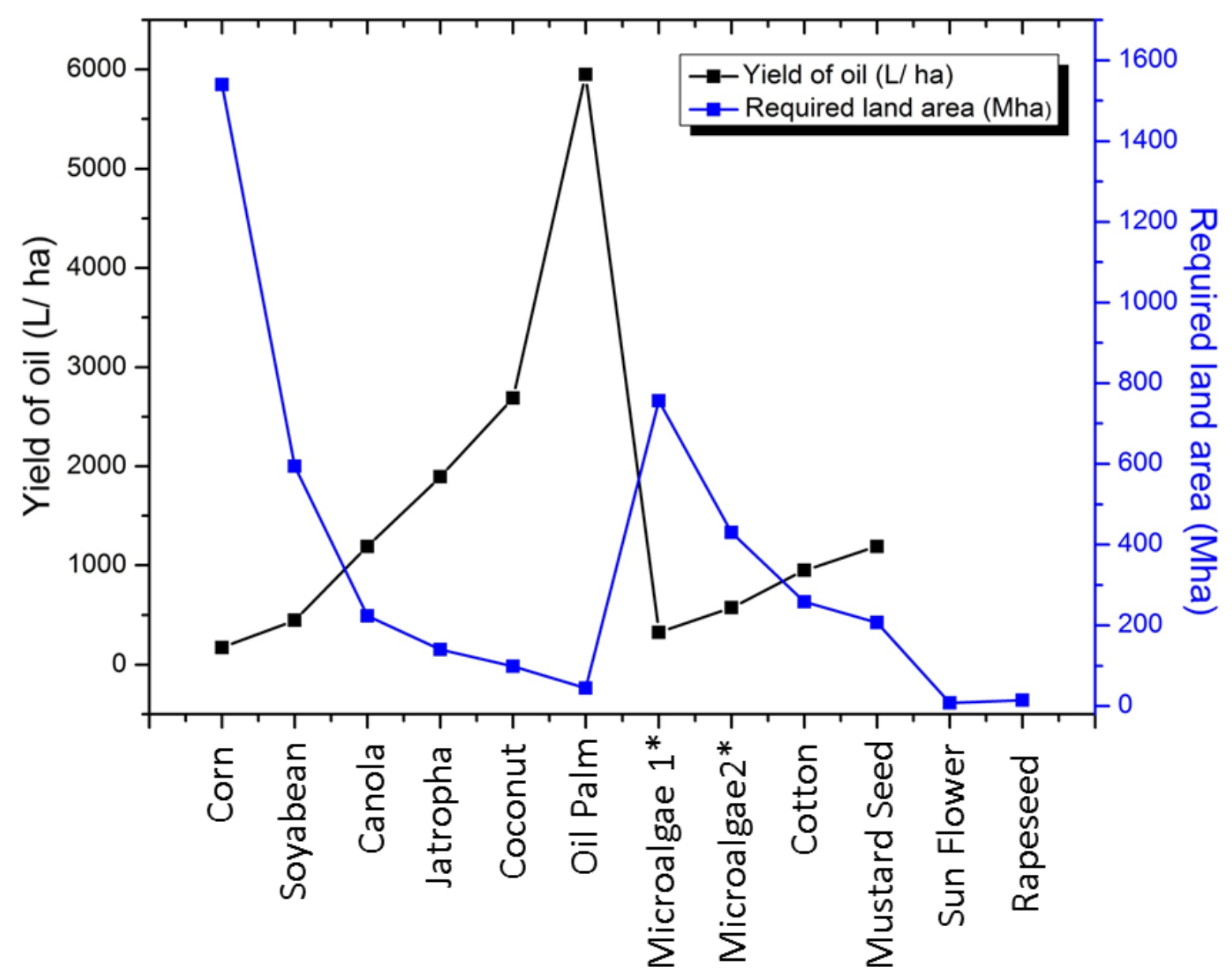

Figure 5. Oil yield and land requirement by microalgae and other energy crops. Microalgae $1 *$ refers to $40 \%$ oil (\% dry weight) in biomass and Microalgae $2 *$ to $20 \%$ oil (\% dry weight) in biomass (adapted from [16]). 


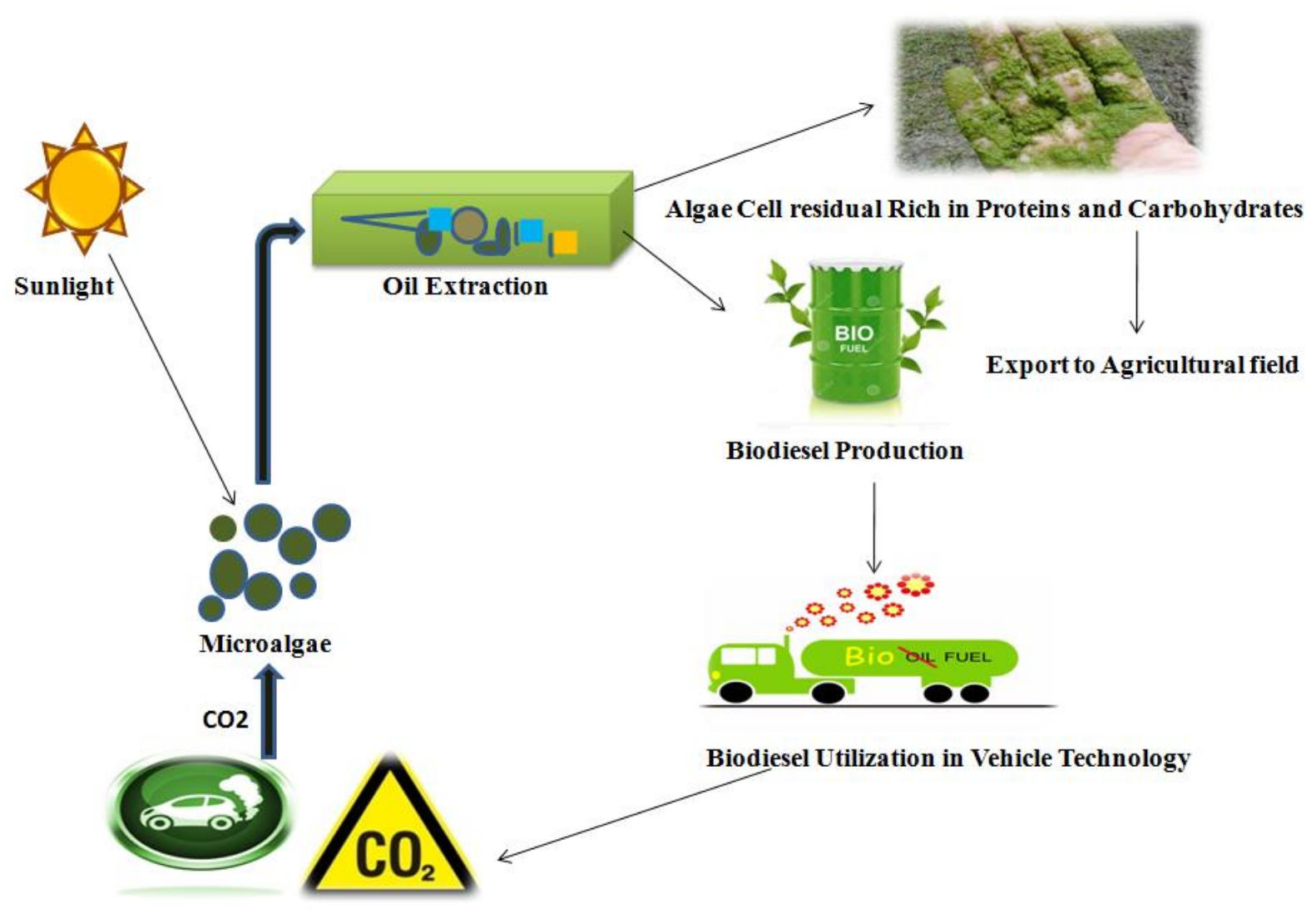

Release of CO2 After Biodiesel Combustion

Figure 6. A carbon neutral process of microalgae to balance the amount of carbon in the environment. 


\section{Tables with captions}

Table 1. Chemical composition of algae expressed on dry matter basis.

\begin{tabular}{|c|c|c|c|c|}
\hline Strains & Protein $(\%)$ & $\begin{array}{l}\text { Carbohydrates } \\
(\%)\end{array}$ & Lipids (\%) & References \\
\hline Scenedesmus obliquus & $50-56$ & $10-17$ & $12-14$ & [16] \\
\hline Scenedesmus quadricauda & 47 & - & 1.9 & [17] \\
\hline Scenedesmus dimorphus & $8-18$ & $21-52$ & $16-40$ & [16] \\
\hline Chlorella vulgaris & $51-58$ & $12-17$ & $14-22$ & [17] \\
\hline Chlorella pyrenoidosa & 57 & 26 & 2 & {$[17]$} \\
\hline Spirogyra sp. & $6-20$ & $33-64$ & $11-21$ & [16] \\
\hline Dunaliella bioculata & 49 & 4 & 8 & {$[17]$} \\
\hline Dunaliella salina & 57 & 32 & 6 & {$[17]$} \\
\hline Euglena gracilis & $39-61$ & $14-18$ & $14-20$ & [17] \\
\hline Prymnesium parvum & $28-45$ & $25-33$ & $22-38$ & [17] \\
\hline Porphyridium cruentum & $28-39$ & $40-57$ & $9-14$ & {$[18]$} \\
\hline Spirulina platensis & $46-63$ & $8-14$ & $4-9$ & [16] \\
\hline Spirulina maxima & $60-71$ & $13-16$ & $6-7$ & [17] \\
\hline Synechoccus sp. & 63 & 15 & 11 & [18] \\
\hline Anabaena cylindrical & $43-56$ & $25-30$ & $4-7$ & [18] \\
\hline
\end{tabular}


Table 2. Yield of different crops and microalgae oil.

\begin{tabular}{cccc}
\hline Serial No. & Oil producers & Oil yield (liters per hectare) & References \\
\hline 1. & Microalgae & $1,00,000$ & {$[18]$} \\
\hline 2. & Castor & 1413 & {$[18]$} \\
\hline 3. & Coconut & 2689 & {$[18]$} \\
\hline 4. & Palm & 5366 & {$[18]$} \\
\hline 5. & Safflower & 779 & {$[18]$} \\
\hline 6. & Sunflower & 952 & {$[18]$} \\
\hline 7. & Jatropha & 741 & {$[37]$} \\
\hline 8. & Canola & 974 & {$[37]$} \\
\hline 9. & Corn/maize & 172 & {$[37]$} \\
\hline 10. & Soyabean & 636 & {$[37]$} \\
\hline
\end{tabular}

Table 3. Acid and alkaline catalysts used in transesterification reaction.

\begin{tabular}{lllc}
\hline S. No. & Acid catalysts & Alkaline catalysts & References \\
\hline 1 & Hydrochloric acid $(\mathrm{HCl})$ & Sodium methoxide $(\mathrm{SM})$ & {$[65]$} \\
\hline 2 & Sulphuric acid $\left(\mathrm{H}_{2} \mathrm{SO}_{4}\right)$ & Sodium hydroxide & {$[65]$} \\
& & $(\mathrm{NaOH})$ & \\
\hline 3 & Boron trifluoride $\left(\mathrm{BF}_{3}\right)$ & Potassium hydroxide & {$[66]$} \\
& & $(\mathrm{KOH})$ & \\
\hline
\end{tabular}


Table 4. Oil Content of different species of microalgae and other energy crops (adapted from Rekha et al., 2012).

\begin{tabular}{|c|c|c|c|}
\hline S. No. & Name of species & Oil content $(\% \mathrm{dw})$ & References \\
\hline 1. & Ankistrodesmus & $28-40$ & [73] \\
\hline 2. & Botryococcus braunii & $29-75$ & {$[74,75]$} \\
\hline 3. & Chlorella sp. & 29 & [76] \\
\hline 4. & Dunaliella tertiolecta & $36-42$ & {$[39,77]$} \\
\hline 5. & Isochrysis sp. & $7-33$ & [78] \\
\hline 6. & Thalassiosira pseudonana & $21-31$ & [79] \\
\hline 7. & Cylindrotheca sp. & $16-37$ & {$[70]$} \\
\hline 8. & Nannochloropsis salina & 32.13 & {$[80]$} \\
\hline 9. & Nitzschia sp. & $45-47$ & {$[80]$} \\
\hline 10. & Phaeodactylum tricornutum & $20-30$ & {$[80]$} \\
\hline 11. & Schizochytrium sp. & $50-77$ & [25] \\
\hline 12. & Heterotrophic C. protothecoides & 57.9 & {$[25]$} \\
\hline 13. & C. protothecoides & 18 & {$[20]$} \\
\hline 14. & C. marina & 70.00 & [20] \\
\hline 15. & S. costatum & 87.00 & [20] \\
\hline 16. & Chlorella minutissima & 57 & {$[11]$} \\
\hline 17. & Chlorella sorokiniana & 22 & {$[81]$} \\
\hline 18. & Nitzchia sp. & $45-47$ & {$[82]$} \\
\hline 19. & Castor & 33.40 & [81] \\
\hline 20. & Jatropha & 62.20 & [81] \\
\hline 21. & Coconut & 57.40 & [81] \\
\hline 22. & Soyabean & $9.40-37.80$ & [81] \\
\hline 23. & Ground nut & 51.20 & {$[81]$} \\
\hline
\end{tabular}


Table 5. Some notable bio products of microalgae with their numerous industrial applications.

\begin{tabular}{|c|c|c|c|}
\hline S.No. & Products & Industrial activities / applications & References \\
\hline 1. & Caretenoides & $\begin{array}{l}\text { Cosmetic industry; rich source of pro- } \\
\text { vitamin A. Acts as safeguard to skin } \\
\text { from UV light. }\end{array}$ & {$[86]$} \\
\hline 2. & Phycocolloids & $\begin{array}{l}\text { Pharmaceuticals; these are } \\
\text { polysaccharides having antitumor. } \\
\text { Anticoagulant, antioxidant and } \\
\text { antiviral activity. }\end{array}$ & [87] \\
\hline 3. & Lectins & $\begin{array}{l}\text { Cell biology; Lectins are } \\
\text { carbohydrates binding proteins, found } \\
\text { in many biological membranes. It can } \\
\text { be best studied in agro bacterium } \\
\text { tumefacien based infection of } \\
\text { nodules. }\end{array}$ & {$[88]$} \\
\hline 4. & $\begin{array}{l}\text { Mycosporine-like } \\
\text { amino acids } \\
\text { (MACs) }\end{array}$ & $\begin{array}{l}\text { Cosmetics and chemical industries; } \\
\text { algae have proficiency to synthesize } \\
\text { MACs while other organisms get it } \\
\text { by mutual transfer. } \\
\text { These are used as UV light guards } \\
\text { and used in number of products such } \\
\text { as cosmetics, paints, varnish, plastics, } \\
\text { and medicines etc. }\end{array}$ & [89] \\
\hline 5. & $\begin{array}{l}\text { Terpens and } \\
\text { latexes }\end{array}$ & $\begin{array}{l}\text { Pharmacological industry; these are } \\
\text { prehalogenating compounds with } \\
\text { pharmacological activities against } \\
\text { number of bacteria, viruses and } \\
\text { tumors. }\end{array}$ & {$[90]$} \\
\hline 6. & Polyketides & $\begin{array}{l}\text { Pharmaceutical industry; used as } \\
\text { chemotherapeutic agents in } \\
\text { pharmaceuticals for synthesis of } \\
\text { many antibiotics such as tetracycline. }\end{array}$ & [91] \\
\hline 7. & $\begin{array}{l}\text { Toxins/ Harmful } \\
\text { Algal Bloom } \\
\text { (HAB) }\end{array}$ & $\begin{array}{l}\text { Causes health hazard to human and } \\
\text { other organism. }\end{array}$ & [92] \\
\hline 8. & $\begin{array}{l}\text { PUFA (poly } \\
\text { unsaturated fatty } \\
\text { acids) }\end{array}$ & Food industry as Food supplement & {$[84]$} \\
\hline
\end{tabular}


Table 6. Summary of microalgae with their benefits and applications in different areas.

\begin{tabular}{llcc}
\hline S. & Benefits of & $\begin{array}{c}\text { Applications in industry and } \\
\text { environment }\end{array}$ & References \\
No. & microalgae &
\end{tabular}

\begin{tabular}{|c|c|c|}
\hline 1. Productivity & $\begin{array}{l}\text { Energy Industry- Microalgae have 300- } \\
\text { times high oil production potential per } \\
\text { hectare than other energy feedstock. } \\
\text { Beside that the utilization of amino acids of } \\
\text { algae biomass alongside fatty acids } \\
\text { increases the economic basis of the } \\
\text { biodiesel production process. }\end{array}$ & [68] \\
\hline $\begin{array}{l}\text { 2. Non- } \\
\text { competitive } \\
\text { with } \\
\text { agriculture }\end{array}$ & $\begin{array}{l}\text { Agricultural field- It can be grown on salty } \\
\text { water, sewage and non-cultivable land such } \\
\text { as arid soil. } \\
\text { Microalgae do not show land effect and } \\
\text { food vs. fuel debate. } \\
\text { Microalgae production do not require } \\
\text { herbicides and pesticides. }\end{array}$ & [37] \\
\hline $\begin{array}{l}\text { 3. Mitigation of } \\
\mathrm{CO}_{2}\end{array}$ & $\begin{array}{l}\text { Environment- Fixation of } \mathrm{CO}_{2} \text { into value } \\
\text { added products. } \\
\text { Burning of algal fuel release } \mathrm{CO}_{2} \text { like fossil } \\
\text { fuel but unlike fossil fuel the } \mathrm{CO}_{2} \text { is } \\
\text { absorbed from the atmosphere by the algae } \\
\text { to grow again (carbon neutral process). }\end{array}$ & [109] \\
\hline $\begin{array}{ll}\text { 4. } & \text { Broad } \\
\text { spectrum } \\
\text { Products } \\
\text { delivery }\end{array}$ & $\begin{array}{l}\text { Different Industries- Cellular components } \\
\text { of microalgae are feed stock for number of } \\
\text { value added products Such as biofuel, } \\
\text { biomethane and biohydrogen. } \\
\text { Microalgae can produce more than } 15,000 \\
\text { noble products, some of those have } \\
\text { discussed earlier. }\end{array}$ & {$[84]$} \\
\hline $\begin{array}{l}\text { 5. Treatment of } \\
\text { waste water }\end{array}$ & $\begin{array}{l}\text { Environment- Microalgae can use dairy } \\
\text { farm based, industrial and municipal waste } \\
\text { water containing high nutrients such as } \\
\text { nitrogen and phosphate in growth media for } \\
\text { its duplication. } \\
\text { Simultaneously treatment of water with } \\
\text { application of microalgae can hamper the } \\
\text { cost effectiveness of production process. }\end{array}$ & [111] \\
\hline $\begin{array}{ll}6 . & \text { Cost } \\
& \text { effectiveness }\end{array}$ & $\begin{array}{l}\text { Cosmetic/food Industry- Biorefinery } \\
\text { products such as biodiesel derived glycerol, } \\
\text { used as substrate in many industries. } \\
\text { Glycerol can be further converted into high } \\
\text { commercial value added products such as } \\
\text { succinic acid, ethylene glycol and Di- } \\
\text { hydroxyacetone etc. }\end{array}$ & {$[86]$} \\
\hline
\end{tabular}




\begin{tabular}{cllc}
\hline 7. Feedstock & $\begin{array}{l}\text { Environment- Conserve Natural Resources, } \\
\text { Production }\end{array}$ & $\begin{array}{l}\text { Protect Virgin and Other High-Value } \\
\text { Habitats, Encourage Sustainable Crops and } \\
\text { Improve Degraded Lands. }\end{array}$ & \\
\hline 8. & Other uses & $\begin{array}{l}\text { Pharmaceuticals- Microalgae can be used as } \\
\text { food supplements in the form of tablets, } \\
\text { powder. } \\
\text { Also used as biofertilizer in agricultural } \\
\text { field. }\end{array}$ & [87] \\
\hline $\begin{array}{l}\text { Zero waste } \\
\text { production }\end{array}$ & $\begin{array}{l}\text { Environment- Recycling of waste and } \\
\text { utilization of residual biomass in animal } \\
\text { feed industries or as manure in agriculture. }\end{array}$ & {$[111]$} \\
\hline $\begin{array}{l}\text { 10. Increase in } \\
\text { socioeconomic } \\
\text { development }\end{array}$ & $\begin{array}{l}\text { Economy- Socioeconomic development will } \\
\text { come in the form of increase in agriculture } \\
\text { sector of food crops and rural livelihood via } \\
\text { increasing jobs. }\end{array}$ & {$[111]$} \\
\hline
\end{tabular}

